\title{
Financial Deepening and Economic Growth in Advanced and Emerging Economies
}

\author{
Keshab Bhattarai* \\ University of Hull, UK
}

November 19, 2014

\begin{abstract}
While over-financing caused crises and slow growth in advanced economies including Germany, France and the UK after 2008, more prudent financial deepening sustained higher economic growth in China and India - two major emerging economies in the world. The actual financial deepening ratios (AFDR) observed in the non-consolidated balance-sheet from the OECD exceeded by factors of $3.5,2.4$ and 5.1 to the optimal financial deepening ratios (OFDR) obtained from the solutions of dynamic general equilibrium (DGE) models of those three advanced economies. The corresponding factors were 2.3 and 0.49 for China and India respectively. Labour intensive production technology and a low OFDR relative to a high AFDR in China allowed it to grow at 10 percent during the period of recent global financial crisis. With a reasonable OFDR and low AFDR India also managed to grow at 6.5 percent. Thus huge gaps between the optimal and actual financial deepening ratios led to massive macroeconomic consequences as observed after the crises in 2008. Smooth, sustainable and efficient economic growth requires adoption of strategies for separating equilibria in line of Miller-Stiglitz-Roth mechanisms avoiding problems of asymmetric information in the process of financial intermediation with as narrower gaps as possible between the AFDRs and OFDRs.
\end{abstract}

JEL Classification: D53, E44, G01, G17, O16, O41

Keywords: financial crisis, financial deepening, economic growth

${ }^{*}$ Business School, University of Hull, HU6 7RX, Hull, UK. Phone: 441482463207; Fax: 441482463484; email: K.R.Bhattarai@hull.ac.uk. This article is based on a paper presented to the European Economics and Finance Society Annual Conference, Berlin, June 20-23, 2013. I am grateful to Sushanta Mallick, an anonymous referee and conference participants for helpful comments and suggestions.

This is the peer reviewed version of the following article: Bhattarai, K. (2015), Financial Deepening and Economic Growth in Advanced and Emerging Economies. Review of Development Economics, 19: 178195. doi: 10.1111 /rode.12133, which has been published in final form at doi: $10.1111 /$ rode.12133. This article may be used for non-commercial purposes in accordance with Wiley Terms and Conditions for selfarchiving. 


\section{Introduction}

Economic crisis of 2008 began with the bursting of the housing market bubble and the credit crisis in the USA and spread around the globe. The Germany, France, UK and other countries in the EU, US and Japan and many other advanced countries were hit hard by the recession. It lowered growth rates and other economic activities in these countries. Output, employment, investment, capital accumulation, exports and imports shrank causing alarming loses of income and deteriorations in living standards of households. Many business firms failed or profit prospects of small, medium and large scale firms became bleak. Governments in these countries initially chose to stimulate the aggregate demand by expanding the public expenditure and cutting taxes bearing increased risks of larger public debts. Central banks reduced the basic interest rate to a record low rate since the beginning of central banking (on January 2009 Federal fund rate has remained close to zero, Bank of England's basic rate is 0.5 percent for five years since 2009; the ECB had adopted similar strategy) in order to expand the liquidity is the system. Credit levels of banks were expanded under the quantitative easing $(\mathrm{QE})$ to compensate for austerity in public spending programmes that accompanied debt reduction programmes in following years. It was surprising to see this financial crisis had little effects on growth rates in the major emerging developing economies such as China and India. China was growing around 10 percent annually and India above 6 percent while France, Germany and UK were in deep recession of about 5 percent. Comparing the results on optimal financial deepening ratios (OFDR) implied by the dynamic general equilibrium (DGE) models of France, Germany, UK, China and India to the actual financial deepening ratio (AFDR) observed in the data from the unconsolidated balance sheets, we argue that while over financing, the nature of casino capitalism, was the cause of long slump in the advanced OECD countries, the optimal or prudent financing brought stability and growth in emerging economies.

Which comes first: the financial development or economic growth? Classical economists had put capital accumulation at the centre of economic growth. For them higher degree of financial deepening through saving and investment activities promotes the level of income and raises the rates of economic growth. No economist can disagree that the economic advancement is impossible 
without a reasonable degree of financial deepening as measured in the ratios of capital stock to GDP. The process of capital accumulation and growth in advanced or emerging economies is enhanced substantially by the financial markets that channel the resources of millions of risk adverse savers to millions of risk neutral borrowers (Fama (2014), Shiller (2014)). Schumpeter (1911) opined that the financial development was a pre-condition for economic growth but Robinson (1952) viewed that the financial development is a by-product of economic growth process. Using four indicators of financial development for about 119 countries for 1960 to 1989 King and Levine (1993) had shown empirical support for the Schumpeterian hypothesis that financial development leads to economic growth over time in contrast to the Robinsonian argument that growth rate of output had little connection to the levels of developments of the financial sector.

Importance of risk minimisation and efficiency of portfolio allocation are at the heart of financial optimisation. Early studies of Sproul (1947), Smith (1958) and Chiang (1959) in this line were instrumental in development of the dynamic general equilibrium framework by Sidrauski (1967) and Tobin (1969) who found correspondence between the balance sheet of the financial system to economic growth. Taking inspirations from a theory of Banking firm in Klein (1971), Shaw (1973) had described the role and process of financial deepening in developing countries illustrating the role of saving and investment in economic development. His propositions were tested by McKinnon (1973), Fry (1978), Boycko, Shleifer and Vishny (1996), Champ, Smith and Williamson (1996) and King and Levine (1993) and Levine (1997) by assessing impacts of finance in economic growth empirically across countries. Hills, Thomas and Dimsdale (2010) and Davies et al. (2010) found that the fluctuations in the banking system were cause of recessions in UK in the past three centuries. Earlier studies on the analysis of causes and consequences of bank-runs (Diamond and Dybvig (1983)), existence of informal finance (Bolnick(1987)), stochastic factors (Boyd and Prescott (1986)) also support that structure of financial system should be right for economic growth (Townsend (1983), and Hansen, Sargent and Tallarini (1999)). Theoretical analysis on liquidity of the banking sector in Epstein and Zin (1989), Fama (1980), Spencer (1984), Roubini and Sala-i-Martin (1992) were empirically validated in more recent works on role of financial sector in economic growth by Giovanni and de Melo (1993), Bank of England (1999, 2001), Arestis, Demetriades and Luintel 
(2001), Raghuram and Zingales (1998), Radelet, Sachs, Cooper and Bosworth (1998), Friedman (2005), Spencer (2008), Gai, Kapadia, Millard and Perez (2008), Cecchetti (2009), Brunnermeier (2009), Taylor (2010). They conclude that the economic growth is impossible without the growth of the financial sector.

The second round of literature in financial deepening and growth took the form of strategic modelling of bargaining a-la Nash (1951). Signalling and coalition formation problem of Shapley (1953) and Shapley and Shubik (1969) and mechanism design from Rogerson (1985), Rasmusen (1987), Milde and Riley (1988), Beaudry and Poitevin (1995), Riley (2001), Cripps (1997), Dasgupta and Maskin (2000) and Roth (2008) have been increasingly applied to assess consequences of adverse selection and moral hazard problems in the financial markets. Consequences of transaction cost in bilateral and multilateral negotiations of Balasko (2003), Kiyotaki and Moore (2006)) and financial deepening (Townsend and Ueda (2006)) shed further lights on neoclassical and neo-Keynesian modeling of linking financial sectors to economic growth in King, Sentana and Wadhwani (1994), Wickens (1995), Chari, Kehoe and McGrattan (2000), Chadha and Nolan (2002) and Covas and Den Haan (2012) subsequently.

General equilibrium impacts of finance on economic growth got special attention in Greenwood and Javanovic (1990), Mercenier and Srinivasan ed. (1994), Altig, Carlstrom and Lansing (1995), Ginsburgh and Keyzer (1997) and Bhattarai (1997). There has been resurgence of interest in the relation between the financial deepening and economic growth recently (Greenwood and Scharfstein (2013), Farmer (2013)) in structural changes (Pilbeam, Olmo and Pouliot (2011), Levine, Pearlman, Perendia and Yang (2013)) after the financial crisis of 2008.

Various studies exist on the evaluation of impacts of financial sector in the economy (Altig et al. (1995), Bacchetta (1992), Bank of England (1999), Brunnermeier (2009), Cecchetti (2009), Champ et al. (1996), Giovanni and de Melo (1993), De Fraja (1991) and Mayer et al. (2009)). How the asymmetry of information on depositors and savers results in volatilities of unimaginable proportions in these markets and affect the choices of economic agents and prospects of economies is analysed using theoretical models and empirical evidences. Financial markets often experience catastrophic failures whenever the expectations of lenders and borrowers do not match market 
Table 1: Financial Deepening in Three EU Economies and in China and India

\begin{tabular}{|c|c|c|c|c|c|c|c|c|c|c|c|c|c|c|c|}
\hline & \multicolumn{3}{|c|}{ France } & \multicolumn{3}{|c|}{ Germany } & \multicolumn{3}{|c|}{ United Kingdom } & \multicolumn{3}{|c|}{ China } & \multicolumn{3}{|c|}{ India } \\
\hline & FA & $\mathrm{Y}$ & $\mathrm{FA} / \mathrm{Y}$ & FA & $\mathrm{Y}$ & $\mathrm{FA} / \mathrm{Y}$ & FA & $\mathrm{Y}$ & $\mathrm{FA} / \mathrm{Y}$ & $\mathrm{FA}$ & $\mathrm{Y}$ & $\mathrm{FA} / \mathrm{Y}$ & FA & $\mathrm{Y}$ & $\mathrm{FA} / \mathrm{Y}$ \\
\hline 2007 & 20.52 & 1.89 & 10.88 & 19.34 & 2.43 & 7.96 & 21.27 & 1.41 & 15.06 & 30.9 & 20.3 & 1.52 & 30.2 & 42.5 & 0.71 \\
\hline 2008 & 19.44 & 1.93 & 10.06 & 19.54 & 2.47 & 7.90 & 28.80 & 1.44 & 19.66 & 33.9 & 22.3 & 1.52 & 33.6 & 44.2 & 0.76 \\
\hline 2009 & 20.39 & 1.89 & 10.81 & 19.75 & 2.37 & 8.32 & 24.90 & 1.40 & 17.76 & 43.5 & 24.3 & 1.79 & 37.4 & 47.9 & 0.78 \\
\hline 2010 & 21.31 & 1.94 & 11.00 & 20.40 & 2.50 & 8.17 & 26.92 & 1.47 & 18.36 & 48.7 & 26.9 & 1.81 & 40.3 & 53.0 & 0.76 \\
\hline 2011 & 21.97 & 2.00 & 10.98 & 20.80 & 2.59 & 8.02 & 29.01 & 1.52 & 19.14 & 55.1 & 29.3 & 1.88 & 43.4 & 56.3 & 0.77 \\
\hline & Data & $\mathrm{OE}$ & nationa & ounts & n) & rilc & W B II & $A=$ & onsolic & Fina & Ass & ind $\mathrm{Y}$ & bot & Trillii & \\
\hline & & & & & & & Fil & $f \times$ & S & & & & & & \\
\hline
\end{tabular}

realities (Friedman (2005), King (1994), Klein (1971), Krugman (1979), Milde and Riley (1988), Prescott and Townsend (1984), Rasmusen (1987), Riley (2001), Rogerson (1985), Sargent (1987), Smith (1958), Spencer (1984), Stiglitz, and Weiss (1981), Sinn (2009, 2010), Miller and Stiglitz (2010), Farmer (2013)). These studies, however, have had not sufficiently addressed on how the financial deepening has impacted on growth. Problems with saving and loan associations in 1980 in the USA, bank runs and failures of giant banks in Japan in 1990s or the collapse of credit and housing markets in the USA and several EU economies recently, with their consequences across the globe are good examples. The credit crunch, bank failures, liquidity crises, stock market crash and bailouts in the UK, EU and USA starting in October, 2008 are recent problems.

Empirical facts emerging from the non-consolidated balance sheets ${ }^{1}$ from the OECD and World Bank summarised in Table 1 provide a basis for the over-financing hypothesis in case of advanced economies and under-developed but prudent structure of the financial sector in case of emerging economies. The financial deepening ratios $(\mathrm{FA} / \mathrm{Y})$ - ratio of financial assets to the GDP, are twice as large in the UK than those in Germany (19.1 and 8.0 respectively). Financial deepening ratios of France around 11, are higher than those of Germany but much smaller than those of the UK. The (FA/Y) - ratios are significantly lower for China (1.88) and very low for India (0.77) compared to those in advanced economies indicating that excess leveraging problems do not appear in case of these emerging economies.

The long run growth is a function of real physical capital not the financial leverages or deriva-

\footnotetext{
${ }^{1}$ The non-consolidated financial assets include currency and deposits, financial derivatives, securities, shares and equities.
} 
tives that promote the artificial financial deepening. Over-financing phenomenon has become more serious in the last two decades in advanced countries. Our general equilibrium computations shows that there is little difference among advanced economies on the real or optimal financial deepening but a large differences on the element of casino capitalism (Sinn 2009, 2010) or asset bubbles and collective illusion (Miller and Stiglitz (2010)). As Farmer (2013) shows these bubbles have adverse consequences on growth particularly when asset prices are as unbounded as above. Mallick and Sousa (2013) show real adverse effects of financial stress created by over expansionary low interest rate policy in the Euro zone using the Bayesian structural VAR and a sign-restriction VAR models. Table 1 also implies that level of financial development is still at the early stage in emerging economies particularly in India with the ratio of financial assets to GDP just around 77 percent, lower than 38 times compared to that in the UK.

This paper shows how economies are vulnerable to over-financing which causes wide ranging inefficiencies, fluctuations in growth of output and other economic activities from time to time. Starting from a simple prototype model of finance in endogenous growth of Pagano (1993) and Bhattarai (2005) type models in section 2 it proceeds to the dynamic multisectoral and multihousehold dynamic general equilibrium (DGE) models of Germany, France, UK, China and India in section 3. Aim of this exercise is to make judgement on over or under financing hypothesis by comparing how the efficient and optimal paths of capital output ratios implied by the dynamic general equilibrium models to the ratios of financial assets to GDP as recorded in the balance sheets of the central banks or the OECD. The conclusions and references are in the final section.

\section{Dynamic Process of Capital Accumulation}

On each trading day financial markets open with sets of assets for transaction, bid-offer processes set the prices of those assets. In theory, exchanges take place at the core which is a non-blocking coalition or Pareto optimal equilibrium in which it is not possible to make one person better off without making another person worse-off. The contract curve is the set of Pareto efficient points at the core. The first and second theorems of welfare economics confirm that the price mechanism in 
a free market economy generates optimal and efficient allocation of resources to economic agents. Similarly the core in a bargaining game and the non-blocking coalition are consistent to rationalities of individuals, groups and coalition involved in the trade. By supper-additivity property of coalition economic gains are maximised under the coalition than by playing alone. It seems that financial markets are prone to coalitions and crises when economic agents play zero sum non-cooperative games without paying any attention to benefits of coalition and cooperation (Gale (1986)). Even when the agreements are made for cooperation, questions remain on whether such coalitions are stable and sustainable. There are always tendencies in these financial markets for one player to cheat others in order to raise personal gain under information asymmetry in the short run. However, it is unlikely that any player can fool all others in the long run. They will discover such cheating in subsequent periods. It results in lack of trusts and collapse of the financial markets. This is what happened during the financial crisis.

Economic models characterise the optimal allocation of resources as a result of the complex bid and offer interactions among economic agents. Their preferences are non-satiable, strictly convex and continuous. Debreu and Scarf (1963) had proven the equivalence of a competitive equilibrium to the core of the game for economies with and without production by contradiction. Scarf (1967) theorem states that a balanced $n$ person game has a non-empty core that is equivalent to the allocation at the core in the competitive equilibrium. He stated "an exchange economy with convex preferences always gives rise to a balanced $n$ person game and such will always have a non-empty core (Scarf (1967))." Theoretical generalisations of a dynamic general equilibrium model based on classical assumptions or of the coalition and bargaining games, may be summarised using a diagram as in Figure 1 where the $\mathrm{E}-\mathrm{E}$ is allocations at the core, $\mathrm{LL}$ is the market valuations of lenders; $\mathrm{BB}$ is the market valuation of borrowers. Deviations in the position of borrowers (BB) and lenders (LL) from the dynamically efficient equilibrium path (EE) reflect subjective differences in the assessment of prospects of financial assets. This is the reason for trades among lenders and borrowers. Wide fluctuations in these were the sources of cycles that were observed during the financial crisis that started in 2008. 


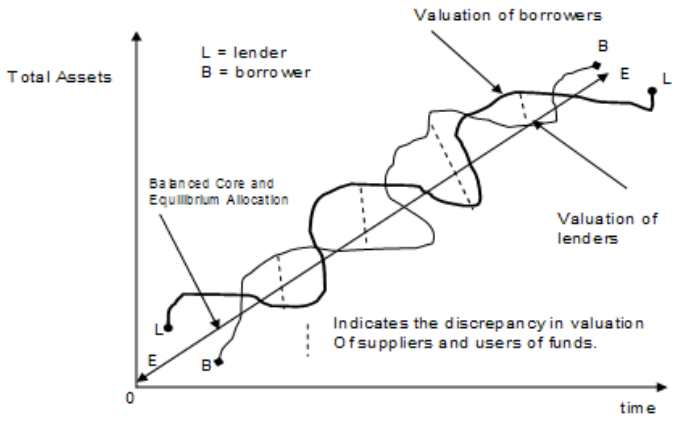

Figure 1: Equilibrium and Core in Asset Markets Over Time

The main intuitive points could be summarised as:

1. Assets are results of consumption saving behavior resulting from the intertemporal optimisation of households or firms.

2. There is an equilibrium allocation path, EE, for each time period of the economy that is at the core of the equilibrium.

3. Lenders and borrowers start with different amounts of endowments and bargain continuously in order to gain more from the transaction, along LL and BB paths.

4. Underlying productivity and preferences cause differentiations in valuation by the buyers and sellers in asset markets. Therefore the valuation can be generalised in $n$ number of cases.

5. Corrective measures are taken by individuals or the policy makers when these valuations significantly deviate away from the underlying equilibrium, destabilising the whole financial system.

6. The asset accumulation profiles can contain overlapping generations and have infinite lives in contrast to individual traders with finite lives.

7. There are gains from trading in the financial markets. Whether the lenders or the borrowers get the larger shares of this gain depends on their bargaining power and prospects of credible coalitions, which keep changing with time.

Above dynamic economy can be expressed with a simple stochastic technology $Y_{t}=z_{t} K_{t}$, where $z_{t} \sim N\left(0, \sigma^{2}\right)$ represents the stochastic shocks in spirit of Wickens (1995) or Price (1997) or more recently in Levine et al. (2013). Capital accumulation takes the form $I_{t}=K_{t+1}-(1-\delta) K_{t}$, and amount of investment deviates from saving depending on the efficiency of financial markets $(0<\phi<1), \quad I_{t}=\phi S_{t}$. Assuming market clearing $Y_{t}=C_{t}+S_{t}$ and a steady economy $K_{t+1}=$ 
Table 2: Endogenous growth with financial efficiency

\begin{tabular}{|l|l|l|l|l|l|}
\hline Parameters & $\delta$ & $\phi$ & $y_{0}$ & $z$ & $s$ \\
\hline CIA & 0.02 & 0.95 & 1 & $(0.15,0.05)$ & 0.15 \\
\hline
\end{tabular}

$(1+g) K_{t} ; \frac{I}{Y}=\frac{\phi S}{Y}$ and the parameters $z, \phi, s$ and $\delta$ in Table 2 determine the growth rate of the economy as shown in Fig. 2 that shows how the growth rates (measured in verticle axis) move over time (horizontal axis shows $t_{1}$ to $t_{100}$ periods) .

$$
g=z \frac{I}{Y}-\delta=z \phi s-\delta
$$

$\left[\because I_{t}=\phi S_{t}=(1+g) K_{t}-(1-\delta) K_{t}=(g+\delta) K=(g+\delta) \frac{Y}{z}\right]$.

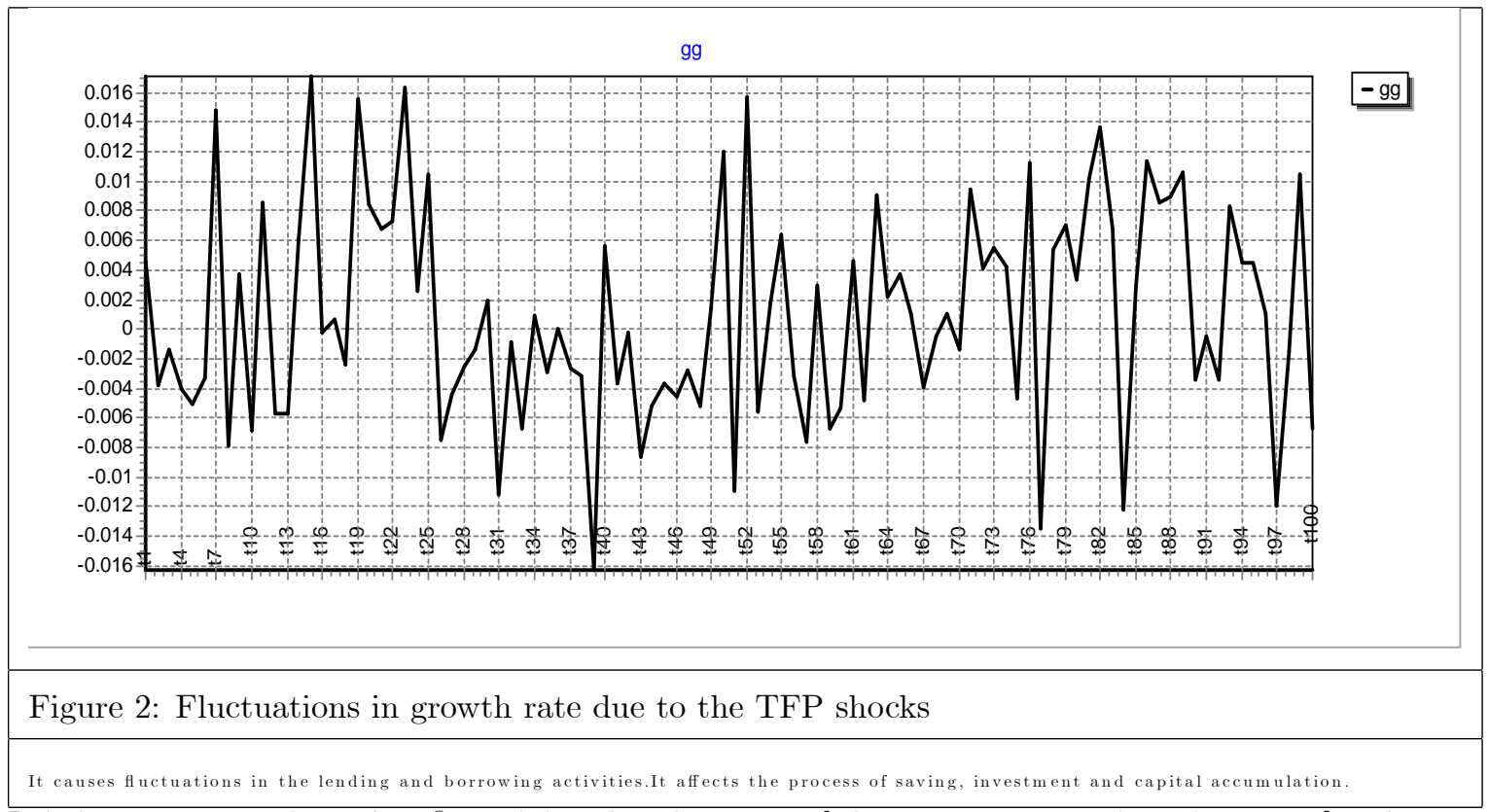

It is important to show that financial and real sectors of the economy are mirror images of each other using an asset accumulation equation as:

$$
A_{t}\left(1+\widehat{r}_{t}\right)+W_{t}-C_{t}=A_{t+1}
$$

where $C_{t}$ is consumption, $A_{t}$ financial assets, $W_{t}$ endowment, and $\widehat{r}_{t+1}$ return to asset net of tax and depreciation rate; $\widehat{r}_{t}=\left(1-\tau_{k}\right)(r-\delta)$ with $r$ the real interest rate, $\delta$ rate of depreciation 
and $\tau_{k}$ capital income tax. When $\tau_{k}=0,(2)$ can be re-written as:

$$
A_{t} r_{t}+W_{t}-C_{t}-\left\{A_{t+1}-(1-\delta) A_{t}\right\}=0
$$

Now replacing $A_{t}$ by $K_{t}$ and using definition of income $Y_{t}=A_{t} r_{t}+W_{t}=C_{t}+I_{t}$

$$
Y_{t}-C_{t}-\left(K_{t+1}-(1-\delta) K_{t}\right)=0 ; \quad \Longrightarrow \Longrightarrow Y_{t}=C_{t}+I_{t}
$$

Thus the stocks of financial assets must balance to the stocks of physical capital in an economy but their values are sensitive to market conditions. In theory, mechanisms of incentive compatible contracts contained in Maskin and Tirole (1990) and Roth (2008) could be applied to separate normal borrower and lenders from risky ones under asymmetric information to solve moral hazard or adverse selection problems required to efficient equilibrium path EE by minimising gaps in their evaluations as shown above by LL and BB lines in Figure 1. Kiyotaki and Moore (2006) illustrate importance of the bilateral and multilateral commitment in maintaining the efficiency of the financial system $(\phi)$. In a growth model with money Sidrauski (1967) had provided a general equilibrium model of growth with finance. However it is our view that policy analyses should be based in more detailed assessment of the structural features of the economy as found in the microconsistent dataset for consumption, production, public sector and trade. A DGE model of financial deepening with realistic micro-foundation for analysis of efficiency, growth and redistribution is the best model for such analysis as discussed in the next section.

\section{Finance in a Dynamic General Equilibrium Model}

A dynamic general equilibrium model properly accounts for the intertemporal preferences of households between the current and future consumption (and saving), long run decision of investors in accumulating capital and the policies of government that often distorts positively or negatively and affects on choices of firms and households. With the increasing level of globalisation, capital now

flows more swiftly from one country to another causing volatility in the values of financial assets, 
causing bubbles as shown by Miller and Stiglitz (2010) or Sinn (2010). It does not settle down until the investors find the best return from their investments. It frequently results in runs, panics or exuberances as shown in Figures 1 and 2 above. Theoretical analysis is found in Greenwood and Boyan (1990), Fama (1980), Levine (1997), Boyd and Prescott (1986), Epstein and Zin (1989), Townsend (1983)), Hansen, Sargent and Tallarini (1999), Chari, Kehoe and McGrattan (2000), Raghuram and Zingales (1998), Benarji and Basu (2009), econometric studies in Arestis, Demetriades and Luintel (2001), and Pilbeam et al. (2011) but very few applied works exist for the financial sector in a dynamic general equilibrium context (Mercenier and Srinivasan (1994)). Therefore it is pertinent to present a generic structure of a dynamic general equilibrium model here and to apply it to France, Germany and the UK as well as to China and India to study long run impacts of financial deepening, particularly in finding how over-financing in advanced countries compares to more prudent financing in emerging economies.

\subsection{Consumers}

Consumers are forward looking in the model. They are interested in smoothing out their life time consumption in order to guarantee a certain level of utility or standard of life for each period in their life, given inter-temporal discount factors $\beta_{h}$. This requires intertemporal optimisation over the life time, maximising lifetime utility $\left(U_{0}^{h}\right)$ as in (5) given the life-time income (7) and budget constraints (8).

$$
\begin{gathered}
U_{0}^{h}=\sum_{t=1}^{\infty} \beta_{h}^{t} U_{t}^{h} ; \quad 0<\beta_{h}^{t}<1 \\
U_{t}^{h}=U\left(C_{i, t}^{h}, L_{t}^{h} ; \sigma_{c}\right)
\end{gathered}
$$

Each consumer starting from initial endowment of physical capital $\left(K_{0}^{h}\right)$ and labour time $\left(L S_{0}^{h}\right)$ makes decision to consume $\left(C_{i}^{h}\right)$ and work $\left(L S_{t}^{h}=\bar{L}_{t}^{h}-L_{t}^{h}\right)$ and save from its full income $\left(I_{t}^{h}\right)$ in each period leaving it to the banking system to channel those savings to the potential investors. The life time income $\left(I_{0}^{h}\right)$ of household $h$ : 


$$
\begin{aligned}
I_{0}^{h} & =\left[\sum_{t=0}^{\infty} e^{-\rho t} \sum_{i=1}^{N}\left\{P_{i, t}\left(1+t_{i}\right) C_{i, t}^{h}\right\}+w_{t}^{h}\left(1-t_{l}\right) L_{t}^{h}\right] \\
& =\sum_{t=0}^{\infty} e^{-\rho t} I_{t}^{h}=\left[\sum_{t=0}^{\infty} w_{t}^{h}\left(1-t_{l}\right) \bar{L}_{t}^{h}+r_{t}\left(1-t_{k}\right) K_{t}^{h}\right]
\end{aligned}
$$

Households supply factors of production, capital and labour, $K_{t}^{h}$ and $L S_{t}^{h}$, to firms. They receive net of tax wage income in return to labour supply $\left[w_{t}^{h}\left(1-t_{l}\right) L S_{t}^{h}\right]$ and capital income $\left[r_{t}\left(1-t_{k}\right) K_{t}^{h}\right]$ in return to their investment. They pay taxes on their capital and labour incomes and receive transfer payments $\left(R_{t}^{h}\right)$ from the government on the mean tested basis.

$$
\sum_{t=0}^{T} \sum_{i=1}^{N} P_{i, t}\left(1+t_{c i}^{h}\right) C_{i, t}^{h}=\sum_{t=0}^{T}\left[r_{t}\left(1-t_{k}\right) K_{t}^{h}+R_{t}^{h}+w_{t}^{h}\left(1-t_{l}\right) L S_{t}^{h}\right]
$$

Households take market price of commodities $\left(P_{i, t}\right)$, wage rates $\left(w_{t}^{h}\right)$ and the rental rate $\left(r_{t}\right)$ as given while solving their own problem.

\section{$3.2 \quad$ Firms}

Firms are central to the supply of goods and services. Given the production technology optimal choices of inputs are made to maximise profit in each period and over the model horizon. Entry and exit is allowed with regulations to maintain a competitive economy. Therefore in each period, firms compare prices of inputs and products $\left(r_{i, t}, w_{t}^{h}, p_{i, t}, p e_{i, t}, p m_{i, t}\right)$ and determine the optimum level of output that would maximise inputs. Implicitly the level of output depends on relative prices of inputs and outputs, technology and elasticity parameters as:

$$
\begin{aligned}
& Y_{i, t}=F_{i}\left[K_{i, t}\left(r_{i, t}, w_{t}^{h}, p_{i, t}\right), p, L_{i}\left(w_{t}^{h}, p_{i, t}\right), A_{i}, \sigma_{c}\right] \\
& \sum_{t=0}^{T} P_{i, t} Y_{i, t}=\sum_{t=0}^{T}\left[r_{t}\left(1+t_{k}\right) K_{i, t}+\sum_{h=i}^{H} w_{t}^{h}\left(1+t_{l}\right) L_{i, t}^{h}\right]
\end{aligned}
$$

The structure of inputs and levels of technology may differ for firms operating in different sectors 
- agriculture, manufacturing, services, but all of them are interested to maximise total profit given the process of capital accumulation, $K_{i, t}=\left(1-\delta_{i, t}\right) K_{i, t-1}+I_{i, t}$.

\subsection{Trade}

Economies modelled here are price takers in the global market except that they need to balance their trade over time. Adjustment in the real exchange rates brings such balance in the value of imports $\left[\sum_{t=0}^{T} \sum_{i=1}^{N} P M_{i, t} M_{i, t}\right]$ and exports $\left[\sum_{t=0}^{T} \sum_{i=1}^{N} P E_{i, t} E_{i, t}\right]$ and net flows of capital $\left[ \pm F L_{t}\right]$.

$$
\sum_{t=0}^{T} \sum_{i=1}^{N} P E_{i, t} E_{i, t}=\sum_{t=0}^{T} \sum_{i=1}^{N} P M_{i, t} M_{i, t}
$$

or,

$$
\sum_{i=1}^{N} P E_{i, t} E_{i, t}-\sum_{i=1}^{N} P M_{i, t} M_{i, t}= \pm F L_{t}
$$

Real exchange rate the ratio of weighted aggregate price indices of imports and exports are determined by $P E_{i, t}$ and $P M_{i, t}$ and thus were results of the flows of imports and exports.

\subsection{Government}

Government provides public services like law and order, education and health, social security and pension and protection of environment to households and firms and adds to the public capital by investing in economic infrastructure, health and education. These expenditures $\left(G_{t}\right)$ enhance productivity of workers and make these economies more competitive in the global market. In a dynamic economy the public spending should balance to the public revenue as shown in (13).

$$
\sum_{t=0}^{\infty} e^{-\rho t} R V_{t} \lessgtr \sum_{t=0}^{\infty} e^{-\rho t}\left(G_{t}+R_{t}^{h}\right)
$$

and,

$$
R V_{t}=\sum_{h=1}^{H} \sum_{i=1}^{N} P_{i, t} t_{c i}^{h} C_{i, t}^{h}+\sum_{i=1}^{N} \sum_{h=i}^{H}\left(w_{t}^{h} t_{l} L_{i, t}^{h}+r_{t}\left(1+t_{k}\right) K_{i, t}\right)
$$


Government collects revenue $\left(R V_{t}\right)$ through direct taxes on income of households and firms and indirect taxes on their consumption. The optimal levels of public expenditure and revenues are set when the benefits from the public spending equal the costs of public funds in equilibrium.

\subsection{General equilibrium in markets}

A competitive equilibrium in these economies are given by a set of relative price system $\left(r_{i, t}, w_{t}^{h}\right.$, $\left.p_{i, t}, p e_{i, t}, p m_{i, t}\right)$ and allocations, $\left(C_{i, t}^{h}, Y_{i, t}, K_{i, t}, I_{i, t}, E_{i, t}, M_{i, t}, L_{t}^{h}, L S_{t}^{h}\right)$ that are consistent to optimisation problem of households and firms as stated in (5) and (9) given their constraints (7) and (10). Financial assets $\left(F_{i, t}, F_{t}\right)$ are mirror effects of physical assets $\left(K_{i, t}, K_{t}\right)$. Thus the dynamic economy is run efficiently by the market clearing relative price system as the prices of commodities and services and factors of production continue to adjust until demands are balanced to supplies in each market.

\subsection{Financial Deepening}

Optimal financial deepening $\left(F_{t}\right)$ is the result of the growth process in the economy and is derived from the optimal financial deepening across production sectors $\left(F_{i, t}\right)$ through investment and saving activities. These reflect the real book (market) values of stocks and bonds of firms operating in these industries. Banks channel funds saved by households or enterprises for investment by firms at the real interest rate that matches cost and productivity of funds to the firms. The degree of real financial deepening then is indicated by the ratio of capital stocks to the GDP.

$$
F_{t}=\frac{K_{t}}{Y_{t}} ; \quad F_{i, t}=\frac{K_{i, t}}{Y_{i, t}} ; \quad F_{t}=\sum_{i=1}^{N} F_{i, t} ; \quad K_{t}=\sum_{i=1}^{N} K_{i, t} ; \quad Y_{t}=\sum_{i=1}^{N} Y_{i, t}
$$

This real measure of optimal financial deepening, resulting from the optimisation behavior of consumers and firms in the economy, should equal to the ratio of financial assets to GDP in the financial market in an ideal world. Such intertemporal equilibria is guaranteed by the flexibility of prices, wages and interest rates in the economy. Imbalances either due to the rigid or inflexible prices cause market imperfections or crises. 
Good financial policies result in right set of accumulation process and higher growth rate of the economy over periods. Wrong financial sector policies lead to mismatch between the volumes borrowed and lent, that often manifests in terms of bail outs or subsidies or preferential treatment of one sector against another. These imbalances distort the accumulation process ultimately reducing the prospects of the economy in the long run.

\section{Optimal verses Actual Financial Deepening Ratios}

The applied general equilibrium model stated above was used to assess prospects of financial development in three economies each of which consisted of eleven sectors of goods and services, capital assets differentiated by sectors and labour differentiated by skills. Each model has a horizon of seventy five years from 2006 to 2080.

The micro-consistent data for this model is taken from the input output table published by the OECD in 2006 for Germany, France, UK, China and India (Appendix Tables C1 - C5 available upon request). This data set provides information on the actual values for demand supply balances of firms, revenue and expenditure of the government, saving and investment balance for the private sector and the export-import balance for the economy.

A number of assumptions are made regarding the nature of the steady states among these economies. First, the bench mark rate of return on capital stock is chosen to be the natural rate of interest $(r)$ for each country. Information about the rate of deprecation of capital $\left(\delta_{i}\right)$ in each sector is obtained from the historical data and tested with sensitivity analyses. The steady state growth rates $\left(g_{i}\right)$ are made consistent with the historical growth rates for each sector. The parametric values of $r, \delta_{i}$ and $g_{i}$ define the reference path of the economy. Elasticities of substitution in consumption $\left(\sigma_{c}\right)$ and production $\left(\sigma_{p}\right)$ are based on the literature. Fundamentals to all these rest on the optimising behavior of households regarding the division of labour between leisure $\left(L_{t}^{h}\right)$ and work $\left(L S_{t}^{h}\right)$ and division of income between consumption $\left(C_{t}^{h}\right)$ and saving $\left(S_{t}^{h}\right)$. Tax rates and

transfers $\left\{t_{c}, t_{w}, t_{k}, R_{t}^{h}\right\}$ are retained for all sectors except for the financial and real estate sectors in the counter factual analyses. Model is applied for policy analysis only after the calibration of 
Table 3: Optimal and actual financial deepening ratios and growth rates for 2008-2009

\begin{tabular}{|l|c|c|c|c|}
\hline Parameters & OFDR & AFDR & OFR (\%) & GR 2008-12 \\
\hline France & 3.16 & 10.98 & $3.5(7.8)$ & 0.11 \\
\hline Germany & 3.31 & 8.02 & $2.4(4.7)$ & 0.77 \\
\hline UK & 3.24 & 19.12 & $5.1(15.9)$ & -0.60 \\
\hline China & 0.81 & 1.88 & $2.3(1.1)$ & 9.30 \\
\hline India & 1.54 & 0.78 & $0.49(-0.8)$ & 6.50 \\
\hline Note: OFDR and AFD R are optimal and actual financial deepeing ratios; OFR over financing ratio \\
\hline
\end{tabular}

the benchmark economies.

\subsection{Balance-sheet FA ratios compared to optimal capital deepening ra- tios}

The general equilibrium theory provides a very solid framework for analysis of results obtained by solving for more than 14 thousand variables simultaneously for France, Germany, UK, China and India. Results on optimal and actual financial deepening, the ratios of financial assets to GDP, relevant for this paper are summarised in Table 3 (Detailed solutions of these models in excel to be available upon request.)

The overall optimal real financial deepening ratios (OFDR) from the general equilibrium models, as presented in Table 3, are consistent across countries; these are found to be higher for advanced countries at around 3.16 in France, 3.31 in Germany and 3.24 for the UK. These are lower for emerging economies at around 0.81 for China due to primarily labour intensive production process but 1.54 for India which seems to be more capital intensive in production than China. These are sensible results and consistent to the converging patterns of economic growth across advanced countries.

The actual ratios of financial deepening (AFDR) reported in Table 1 earlier based on figures from the OECD's non-consolidated balance sheets for France, Germany and the UK were 10.98, 8.02 and 19.12 respectively. These ratios exceeded by factors of 3.5, 2.4 and 5.1 than the optimal ratios 
computed from the solutions of the general equilibrium models for France, Germany and the UK respectively as shown in the OFR (over financing ratios) in Table 3. In other words the overfinancing in these countries amount to 7.8, 4.7 and 15.9 times of GDP respectively as shown in the parenthesis in the OFR column. The actual financial deepening ratios (AFDR) were much lower for emerging economies. It was around 1.88 in China and 0.89 in India. The discrepancy between the real and the nominal magnitudes of financial deepening gives credibility to the hypothesis that UK economy is more vulnerable to financial crises as it has more assets originating from the financial derivatives and more subject to the problems caused by asymmetric information. China is overfinanced by 1.1 times of GDP. India is underfinanced up to 80 percent of its GDP; the OFR of 0.49 indicates serious level of under financing in India. The OFR of 2.3 for China means that it is over-financed by a factor of 2.3. Nevertheless the degree of over-financing is twice as much in the UK with the OFR of 5.1 than in China.

Economic growth rates in these models are driven by fundamentals of the financial markets based on the net present value calculations and portfolio selections satisfying the arbitrage conditions across markets. These contain risk-return analysis to minimise risks and maximise returns and insurances to cover unforeseen contingencies. The supply of funds arises from inter-temporal utility maximising consumers and demand for funds for investment originates from profit maximising producers. Subjective discount factors of consumers and depreciation rates of capital are balanced by the real interest rates so that funds are allocated according to the marginal utilities of households or productivities of firms across various sectors leaving regulatory roles to the government for maintaining the law and order to create opportunities for the participants from the private sector. The space of financial sector reforms can also vary across countries.

The proper reforms of financial markets improve efficiency of financial intermediation and brings speedier rate of economic growth by linking the lending and borrowing rates to the fundamentals of demand for and supply of funds; removing controls on credits; by creating right structure of incentives for investors and depositors and freeing up the foreign exchange market from arbitrary decisions and by making it subject to fundamentals of domestic and foreign markets. These mechanism remove repressionary regimes with non inflationary public finance for smooth process of 
capital accumulation, increased liquidity, technical advancement and economic growth, elimination of parallel markets and reducing the proportion of toxic non-performing assets. Liberation and reform mechanisms thus are instrumental in reversing repressionary financial regimes towards more classical free enterprise economy that would promote accumulation and growth in these model economies.

The general equilibrium model results presented above rely on classical economic principles in which the self-adjusting mechanism of the real interest rates would balance demand for and supply of financial assets in a market driven economy and do not contain liquidity trap and credit crunch situations as imagined by Keynes (1936). These results are consistent to literature that has emerged since late 1960s on harmful impacts of financial repressions in works of McKinnon (1968), Shaw (1968), Roubini and Sala-i-Martin (1992) and Stiglitz and Weiss (1981) and more recently in Boyd and Jalal (2012).

Competitive financial markets are perfect in allocating assets as all agents that have complete information and are efficient in processing such information. This assumption, however, is far from perfect. Financial markets are full of asymmetric information, activities of one set of players depend on actions taken by another set of players and the amount of information they have impacts on the likely choices of others. This requires modelling of state contingent incentive compatible mechanisms in this general equilibrium system and is an issue for further investigation.

On-going financial sector reforms can be expected to make these economies more efficient so that the costs of funds decline in the counter factual experiments, where the taxes on the financial sectors are set to minimise distortions relative to the benchmark. Such measures will then result in the higher rate of growth of output, employment and capital stock in almost all sectors even with lower capita output ratios. The financial liberalisation is paying for itself and welfare levels of consumers improve with reforms rather than without it. 


\section{Conclusion}

Solutions of dynamic general equilibrium models of advanced countries Germany, France and UK confirm that the financial crises of 2008 occurred due to over-financing problem. The actual financial deepening ratios (AFDR) exceeded by factors of 3.5, 2.4 and 5.1 to the optimal financial deepening ratios (OFDR) or by 7.8, 4.7 and 15.9 times of GDPs respectively for France, Germany and the UK respectively. In contrast the emerging countries such as China and India with smaller OFDR and AFDR were not only close to the efficiency frontier but also were able to continue their impressive growth rates at about 9.3 and 6.5 percents without being affected by the global financial crisis. While the over-financing (casino capitalism) problem was the cause of deep recession in advanced countries observed after the crisis in 2008, such problem did not exist in emerging economies. Huge gaps between the OFDR and AFDR cause massive macroeconomic fluctuations; smaller gap allows faster growth as these economies are close to the efficiency frontier of financial intermediation required for economic stability and growth. Narrowing gaps between these two ratios required for smooth and sustainable growth, emerging economies were more able to adopt the separating equilibrium strategies in line of Miller-Stiglitz-Roth mechanisms to avoid the problem of asymmetric information in process of financial intermediation and capital accumulation than advanced economies.

\section{References}

[1] Altig D E, C.T. Carlstrom and K.L. Lansing, Computable General Equilibrium Models and Monetary Policy Advice, Journal of Money Credit and Banking, 27(4) (1995):1472-1493.

[2] Arestis P., P. O. Demetriades and K. B. Luintel, Financial Development and Economic Growth: the Role of Stock Markets, Journal of Money, Credit and Banking, 33(1) (2001):16-41.

[3] Bacchetta P. Liberalization of Capital Movements and of the Domestic Financial System, Economica, 59 (236): (1992): 465-474

[4] Bank of England, The Transmission Mechanism of Monetary Policy (1999), London, UK. www.bankofengland.co.uk

[5] Bank of England, Financial Stability Review (2013), London. www. Bankofengland.co.uk.

[6] Balasko Y., Temporary Financial Equilibrium, Economic Theory, 21(1) (2003) 1-18. 
[7] Benati, L.,The 'Great Moderation' in the United Kingdom, Journal of Money,Credit and Banking, 40(1) (2008):121-47.

[8] Banerji S and P Basu, Universal Banking and Equity Risk Premium, Paper presented in CEP Seminar in Hull Business School (2009) .

[9] Bean C., The meaning of internal balance' Thirty years on, Economic Journal, 119 (541) (2009):F442-F460.

[10] Beaudry P and M. Poitevin, Competitive Screening in Financial Markets when Borrowers can Recontract, Review of Economic Studies, 62(3) (1995):401-423

[11] Bhattarai K., General Equilibrium Impacts of Monetary and Fiscal Policies on Welfare of Households in South Asia, Review of Development Economics, 15(4) (2011):745-757.

[12] Bhattarai K., Consumption, Investment and Financial Intermediation in Ramsey Models, $A p$ plied Financial Economics Letters, 1(6) (2005):1-5.

[13] Bhattarai K. R., Financial Deepening and Economic Development in Nepal: A Forward Looking CGE Model with Financial Intermediation, Ph.D. dissertation Northeastern University, Boston, Massachussetts (1997).

[14] Bolnick B. R., Financial Liberalization with Imperfect Markets: Indonesia During the 1970s, Economic Development and Cultural Change, 35(3) (1987): 581-599

[15] Boycko M, A. Shleifer and R. W. Vishny, A Theory of Privatisation, Economic Journal, 106(435) (1996):309-319

[16] Boyd J. H and A. M. Jalal, A new measure of financial development: theory leads measurement, Journal of Development Economics, 99 (2) (2012): 341-357.

[17] Boyd, J.H. and E. C. Prescott, Financial Intermediary-Coalitions, Journal of Economic Theory, 38(2) (1986): 211-232.

[18] Brunnermeier, M. K, Deciphering the Liquidity and Credit Crunch 2007-2008, Journal of Economic Perspectives, 23(1) (2009.): 77-100.

[19] Cecchetti, S. G., Crisis and Responses: The Federal Reserve in the Early Stages of the Financial Crisis, Journal of Economic Perspectives, 23(1) (2009): 51-75.

[20] Chadha J. S. \& C. Nolan, Inflation and price level targeting in a new Keynesian model, Manchester School, 70(4) (2002): 570-595.

[21] Champ B. , B. D. Smith and S. D. Williamson, Currency Elasticity and Banking Panics: Theory and Evidence, Canadian Journal of Economics, 29 (4) (1996): 826-824.

[22] Chari V.V., P. J. Kehoe and E. R McGrattan, Sticky price models of the business cycle: Can the contract multiplier solve the persistence problem?, Econometrica, 66(5) (2000):1151-1179.

[23] Chiang A. C., Instalment Credit Control: A Theoretical Analysis, Journal of Political Economy, 67(4) (1959): 363-376. 
[24] Covas F. and W. J. den Haan, The role of debt and equity finance over the business cycle, Economic Journal, 122 (565) (2012) :1262-1286.

[25] Cripps M. W., Bargaining and the Timing of Investment, International Economic Review, 38(3) (1997): 527-546

[26] Dasgupta P. and E. Maskin, Efficient Auctions, Quarterly Journal of Economics, 115(2) (2000):341-388

[27] Diamond P, D. W. Douglas and P. H. Dybvig, Bank Runs, Deposit Insurance,and Liquidity, Journal of Polotical Economy, 91(3) (1983): 401-419.

[28] Davies R. and P. Richardson, V. Katinaite and M. Manning, Evolution of the UK banking system, Bank of England Quarterly Bulletin, 2010 (Q4) (2010): 321-332.

[29] De Fraja G., Efficiency and Privatisation in Imperfectly Competitive Industries, Journal of Industrial Economics, 39(3) (1991): 311-321.

[30] Epstein L. G. and S E. Zin Substitution, risk aversion and the temporal behavior of consumption and asset returns: A theoretical Framework, Econometrica, 57(4) (1989):937-969.

[31] Fama E.F., Two Pillars of Asset Pricing, American Economic Review, (2014): 104(6): 14671485.

[32] Fama, E. F., Banking in Theory of Finance, Journal of Monetary Economics, 6(1) (1980):39-57.

[33] Farmer R. E. A., Animal Spirits, Financial Crises and Persistent Unemployment, Economic Journal, 123(586) (2013):317-340

[34] Friedman M. A., Natural Experiment in Monetary Policy Covering Three Episodes of Growth and Decline in the Economy and the Stock Market, Journal of Economic Perspectives, 19 (4) (2005):145-150.

[35] Fry M. J., Money and Capital or Financial Deepening in Economic Development?, Journal of Money, Credit and Banking, 10(4) (1978): 464-475.

[36] Gai P., S. Kapadia, S. Millard, A. Perez, Financial Innovation, Macroeconomic Stability and Systemic Crises, Economic Journal, 118(527) (2008): 401-426.

[37] GAMS Development Corporation, GAMS: A User's Guide, Washington DC 20007, USA (1999).

[38] Ginsburgh V and M. Keyzer, The Structure of Applied General Equilibrium Models, MIT Press (1997).

[39] Greenwood J, and B. Javanovic, Financial Development, Growth, and the Distribution of Income, Journal of Political Economy, 98(5) (1990): 1076-1107.

[40] Giovannini A. and M. de Melo, Government Revenue from Financial Repression, American Economic Review, 83(4) (1993): 953-963

[41] Hansen L. P.,Nobel Lecture: Uncertainty Outside and Inside Economic Models, Journal of Political Economy, 122(5) (2014) 945-987 
[42] Hansen L. P., T. J. Sargent and T. D., Tallarini Robust permanent income and pricing, Review of Economic Studies, 66(4) (1999):873-907.

[43] Hills S., R. Thomas and N. Dimsdale, The UK recession in context-what do three centuries of data tell us?, Bank of England Quarterly Bulletin 2010(Q4) (2010): 277-291

[44] King M., E. Sentana and S. Wadhwani, Volatility and Links between National Stock Markets, Econometrica, 62(4) (1994): 901-933

[45] King R. G. and R. Levine, Finance and Growth: Shumpeter Might Be Right, Quarterly Journal of Economics, 108(3), (1993) :717-737

[46] Kiyotaki N. and J. Moore, Financial Deepening, Journal of the European Economic Association, 3(2/3) (2006): 701-713.

[47] Klein M. A., A Theory of the Banking Firm, Journal of Money, Credit and Banking, 3(2) (1971): 205-218

[48] Krugman P., A Model of Balance of Payment Crisis, Journal of Money Credit and Banking, 11(3) (1979): 311-325.

[49] Levine P, J. Pearlman, G. Perendia and B Yang, Endogenous persistence in an estimated DSGE model under imperfect information, Economic Journal, 122 (573), (2013):1287-1312.

[50] Levine R., Financial Development and Economic Growth: Views and Agenda, Journal of Economic Literature, 35(2) (1997):688-726.

[51] Mallick, S.K., and R.M. Sousa, The real effects of financial stress in the Eurozone, International Review of Financial Analysis, (2013): 30: 1-17.

[52] Mayer, C., K. Pence, and S. M. Sherlund, The Rise in Mortgage Defaults, Journal of Economic Perspectives, 23(1) (2009): 27-50.

[53] Maskin E. and J. Tirole, The principal-agent relationship with an informed principle: The case of private values, Econometrica, 58 (2) (1990):379-410.

[54] McKinnon R. I., Money and Capital in Economic Development, the Brookings Institution, Washington D. C (1973).

[55] Mercenier J. and T.N. Srinivasan ed., Applied General Equilibrium and Economic Development: Present Achievement and Future Trends, University of Michigan Press, Ann Arbor (1994).

[56] Milde H. and J. G. Riley, Signaling in Credit Markets, Quarterly Journal of Economics, 103(1) (1988): 101-129.

[57] Miller M and J. Stiglitz, Leverage and Asset Bubbles: Averting Armageddon with Chapter 11?, Economic Journal, 120(544) (2010): 500-518.

[58] Nash J., The Bargaining Problem, Econometrica, 18(2) (1950):155-162.

[59] Nordhaus W.D., Policy Games: Co-ordination and Independence in Monetary and Fiscal Policies, Brookings Papers on Economic Activities 2(1994) (1995): 139-216. 
[60] Pagano M., Financial Markets and Growth: An Overview, European Economic Review, 37(2-3) (1993): 613-622.

[61] Pilbeam K, J.Olmo and W.Pouliot, Detecting the Presence of Insider Trading via Structural Break Tests, Journal of Banking and Finance, 35(11) (2011): 2820-2828.

[62] Price S., Political Business Cycles and Macroeconomic Credibility: A Survey, Public Choice, 92(3/4) (1997): 407-427

[63] Prescott E. C. and R. M. Townsend, Pareto Optima and Competitive Equilibria with Adverse Selection and Moral Hazard, Econometrica, 52(1) (1984): 21-45

[64] Rasmusen E., Moral Hazard in Risk-Averse Teams, RAND Journal of Economics, 18(3) (1987): 428-435.

[65] Radelet S. , J. D. Sachs, R. N. Cooper and B. P. Bosworth, The East Asian Financial Crisis: Diagnosis, Remedies, Prospects, Brookings Papers on Economic Activity, 1998(1), (1998):1-90

[66] Raghuram G. R. and L. Zingales, Financial Dependence and Growth, American Economic Review, 88(3) (1998):559-586.

[67] Riley J. G., Silver Signals: Twenty-Five Years of Screeding and Signalling, Journal of Economic Literature, 39(2) (2001): 432-478.

[68] Rogerson W. P., Repeated Moral Hazard, Econometrica, 53(1) (1985): 69-76

[69] Roth A. E., What have we learned from market design?, Economic Journal, 118(527) (2008) :285-310.

[70] Roubini N. and Sala-i-Martin, Financial Repression and Economic Growth, Journal of Development Economics, 39(1) (1992): 5-30.

[71] Rutherford T.F., GAMS/MPSGE Guide, GAMS Corporation, Washington DC (1998).

[72] Scarf H., Core of n Person Game, Econometrica, 35(1) (1967):50-69.

[73] Shapley L., A Value for n Person Games, Contributions to the Theory of Games II, 307-317, Princeton (1953).

[74] Shapley L. and M. Shubik, On Market Games, Journal of Economic Theory, 1(1) (1969):9-25.

[75] Shaw, E.S., Financial Deepening in Economic Development, Oxford University Press: New York (1973).

[76] Shiller R. J., Speculative Asset Prices, American Economic Review, (2014): 104(6): 1486-1517

[77] Sinn H.W., Risk Taking, Limited Liability and the Banking Crisis, Ifo Institute, University of Munich (2009).

[78] Sinn H.W., Casino Capitalism, Oxford University Press: Oxford (2010).

[79] Smith W. L., The Discount Rate as a Credit-Control Weapon, Journal of Political Economy, 66 (2) (1958) : 171-177 
[80] Sidrauski M., Rational Choice and Patterns of Growth in a Monetary Economy, American Economic Review, 57(2) (1967): 534-544

[81] Spencer P. D., Stochastic Volatility in a Macro-Finance Model of the U.S. Term Structure of Interest Rates 1961-2004, Journal of Money, Credit and Banking, 40(6) (2008): 1177-1215

[82] Spencer P. D., Precautionary and Speculative Aspects of the Behavior of Banks in the United Kingdom Under Competition and Credit Control 1972-1980, Economic Journal, 94(375) (1984):554-568

[83] Sproul A., Monetary Management and Credit Control, American Economic Review, 37(3) (1947): 339-350

[84] Stiglitz, J.E. and A. Weiss, Credit Rationing in Markets with Imperfect Competition, American Economic Review, 71(3) (1981): 393-410.

[85] Townsend, R. M., Financial Structure and Economic Activity, American Economic Review 73(5) (1983): 895-911.

[86] Townsend R.M. and K. Ueda The Financial Deepening, Inequality, and Growth: A ModelBased Quantitative Evaluation, Review of Economic Studies, 73(1) (2006): 251-280

[87] Ventura, J., Growth and Interdependence, Quarterly Journal of Economics, 112 (1) (1997): $57-84$.

[88] Wickens M., Real Business Cycle Analysis: A Needed Revolution in Macroeconometrics (in Controversy: Business Cycle Empirics) Economic Journal, 105(433) (1995):1637-1648. 